\title{
Metacognition Profile of Vocational High School Students in Mathematics Problem Solving Based on Logical Thinking Skills
}

\author{
Mu'jizatin Fadiana 1, Andriani 2 \\ DOI: $10.35445 /$ alishlah.v13i2.376
}

Article Info

Keywords:

Metacognition;

Mathematics problem

solving;

Logical thinking skills

Kata kunci:

Metakognisi

Pemecahan masalah

matematika;

Kemampuan berpikir

logis

\begin{abstract}
This study describes the profile of vocational high school students' metacognitive abilities in mathematics problem solving based on their logical thinking abilities. This research was conducted using descriptive research methods with a qualitative approach. The data was collected using a logical thinking ability test and problem-solving test and. Three students were selected who met different logical thinking stages: the abstract operation stage, the transition stage, and the concrete operational stage. The results showed the subject of the abstract operation stage fulfilled the metacognition stage by redescribing the given problem, knowing the relationship between what was known and what was asked, working on the problem by writing down what was known and asked and entering into the formula and also checking the answer. Transition stage subjects fulfill the metacognition stage by describing initial information and instructions, performing problem-solving steps, and counting to check completed work. The subject of concrete operations fulfills the metacognition stage by stating information and instructions that are nonspecific and detailed. The subject has not been able to state the proper steps to ensure the information's conformity with the problem, and the subject sees what is done by calculating.
\end{abstract}

\begin{abstract}
Abstrak
Tujuan penelitian ini adalah mendeskripsikan profil kemampuan metakognitif siswa SMK dalam menyelesaikan masalah matematika ditinjau dari kemampuan berpikir logisnya. Penelitian ini dilakukan dengan menggunakan metode penelitian deskriptif dengan pendekatan kualitatif. Pengumpulan data dilakukan dengan menggunakan tes kemampuan berpikir logis dan tes pemecahan masalah dan terpilih 3 siswa yang memenuhi tahapan berpikir logis yang berbeda, yaitu tahap operasi abstrak, tahap transisi dan tahap operasi konkrit. Hasil penelitian menunjukkan bahwa subyek tahap operasi abstrak memenuhi tahap metakognisi dengan mendeskripsikan ulang masalah yang diberikan, mengetahui hubungan antara apa yang diketahui dan yang ditanyakan, mengerjakan soal dengan menuliskan apa yang diketahui dan ditanyakan serta memasukkan ke dalam rumus dan juga memeriksa kembali jawaban. Subyek tahap transisi memenuhi tahap metakognisi dengan mendeskripsikan informasi dan instruksi awal, melakukan langkah-langkah pemecahan masalah, dan berhitung untuk mengecek pekerjaan yang sudah selesai. Subyek operasi konkrit memenuhi tahapan metakognisi dengan menyatakan informasi dan
\end{abstract}

\footnotetext{
${ }^{1}$ Universitas PGRI Ronggolawe, Tuban, Indonesia

Email: mujizatinooo@gmail.com

${ }^{2}$ Universitas PGRI Ronggolawe Tuban

Email: andri14ani@gmail.com
} 
instruksi yang diketahui tidak spesifik dan detil, subjek belum mampu menyatakan langkah-langkah yang tepat untuk memastikan kesesuaian informasi dengan masalah dan subjek melihat apa adanya dilakukan benar dengan menghitung.

\section{INTRODUCTION}

Problem-solving is the orientation of mathematics learning in many countries, including Indonesia. It is considered an important and complementary component of the mathematics learning process. It is one of the standard processes and competencies in the mathematics learning process. The learning process of mathematics is oriented towards solving problems that can increase students' thinking ability. Problem-solving is part of the mathematics curriculum, which is very important because students may gain experience in the learning process. Use existing knowledge and skills to be applied to problem-solving that is not routine (Akben, 2020). The 2015 Program for International Student Assessment (PISA) report shows that Indonesia is ranked 63 out of 70 countries in problem-solving capabilities. Besides, more than $60 \%$ of Indonesian students are only able to solve problems below level 2. It indicates the weak ability of students to solve math problems in Indonesia. Furthermore, the importance of mathematics teachers in improving and evaluating the mathematics learning process is due to the low results of Indonesian students' problem-solving abilities. The low ability of students to solve math problems is due to and influenced by many factors.

Problem-solving activities and the mathematics learning process are related to knowledge and procedures involving the operations of students' cognition. However, this also requires students' awareness of thinking to control and regulate their thinking processes. Problem-solving is a complex process that involves metacognition (Hassan \& Rahman, 2017). Besides, practical problem solving can be obtained by providing opportunities for students to apply their metacognitive strategies when solving problems (Hassan \& Rahman, 2017). Therefore, the process of metacognition is needed by students in solving math problems to increase their problem-solving skills.

Metacognition appears at a very young age (Balcomb \& Gerken, 2008). The process of developing metacognitive abilities continues according to the development of the children's age. It means that metacognitive abilities develop with age and are also influenced by exercise (Fisher \& Wood, 2012; Larkin, 2006). The interactions with each other can provide individuals' stimulus to become more aware of their cognitive processes. Since metacognition is present in every individual cognitive development, it requires logical thinking skills to identify the level of individual cognitive development. From different levels of cognitive development, it is hoped that researchers can describe the metacognition abilities of each subject.

Logical thinking skills are the most appropriate way to identify individual cognitive development levels between the concrete and formal operational stages (Fadiana et al., 2019). Logical thinking skills are also considered a characteristic in humans in general and are high-level cognitive skills (Fadiana et al., 2019). Three stages of individual cognitive development using logical thinking skills measures: the concrete stage, the transition stage, and the formal stage (Bitner, 1991; Bunce \& Hutchinson, 1993; Fadiana et al., 2019). In other words, the level of logical thinking ability provides us with information about individual cognitive development.

Vocational high school students are over 12 years of age, where according to Piaget, their cognitive development is at the last stage of cognitive, namely formal cognitive (Ojose, 2015). This development can be seen in students' logical thinking skills and formal theoretical thinking based on propositions and hypotheses. It can be inferred from what can be observed at that time and how abstract thinking begins to be understood (Moore, 2012; Syahbana, 2012). People with the stage of formal thinking can generally think abstractly in classification reasoning, conservation reasoning, theoretical reasoning, combination reasoning, proportional reasoning, functional reasoning, 
controlling variables, analogical reasoning, propositional reasoning, correlational reasoning, probability reasoning (Kincal \& Yazgan, 2010).

However, based on preliminary research results, many vocational high school students are still at the concrete operational stage. This study aims to explore the knowledge and awareness of vocational school students about their cognitive processes. In theory, they should already be in the formal operational stage, but they are still in the concrete operational stage. They become aware of their cognitive processes in solving math problems and factors influencing their metacognition process. Good metacognition in solving problems will also impact learning and achievement (SandiUrena et al., 2011; Sart, 2014). So, the more students know about thinking and learning, namely, the higher their metacognition awareness, the better the learning process and achievement. Metacognition consists of two components, knowledge of cognition and regulation of cognition. Knowledge about cognition includes; declarative knowledge, procedural knowledge, and conditional knowledge. In contrast, the regulation of cognition includes; planning, monitoring, and evaluation. In this study, cognition regulation consists of three components, namely, planning, monitoring and evaluation.

\section{METHODS}

This study used a qualitative approach to describe vocational students' metacognition profile in solving math problems and differences in their logical thinking abilities. The subjects of this study were selected from 36 of Grade $10^{\text {th }}$ students majoring in Industrial Chemistry-1. All students are given a logical thinking ability test adapted from The Galt of Assessment of Logical Thinking (GALT). The logical thinking ability test instrument consists of 12 questions containing six types of reasoning: conservational reasoning, proportional reasoning, controlling variables, probabilistic reasoning, correlation reasoning, combinatoric reasoning. Three students were selected from the logical thinking ability test. Three students were selected who met different logical thinking stages: the abstract operation stage, the transition stage, and the concrete operation stage (Fadiana et al., 2019). The subject is selected based on good communication skills, with good communication skills. It is expected that the subject can convey answers well and in detail about the problems given.

The data collection method used in this study was to interview the subject while working on the metacognition questions. The metacognition test instrument used in this study used mathematical problem-solving tasks related to arithmetic series and series. The selection of relevant questions helps researchers reveal various ways students solve these questions and raises the metacognition steps. The problem-solving steps carried out in this study were Polya's problemsolving steps: planning, monitoring, evaluation. The metacognition test instrument in this study consisted of three questions. Problem I and II are arithmetic sequences problems, and problem III is an arithmetic sequence problem. In the question I, there is an illustration of the taxi fare to be paid per kilometer. The illustration shows that the rate increases with each additional distance traveled. They will form a sequential pattern and be linked to an arithmetic sequence. Question II illustrates the seating arrangement in the cinema building, which is continuously increasing in each row. As in Problem I, this illustration describes a sequential pattern. In contrast to the two previous questions, question III describes the total number of seats in the performance space where each row has a constant increase.

Another instrument used was an interview sheet asked of the subject while working on the metacognition test questions. The questions given are based on the metacognition indicators to be measured. Each instrument used in this study was validated to determine the instrument's relevance and suitability as a measure of the subject's metacognition ability. Therefore every instrument made was validated by the validator. In this study, the validator was a mathematics teacher of grade $10^{\text {th }}$ of vocational high school because it was under the questions to be tested. The data collection process in this study used the steps: (1) determining the subject using the logical thinking ability test, then obtained 3 subjects representing each category of logical thinking; (2) The three subjects are given a 
metacognition test while being interviewed, this activity is carried out separately from each subject to avoid cooperation between subjects and obtain relevant results. Besides, this activity is carried out with the aid of an audiovisual recording device; (3) Making interview transcripts; (4) Data analysis from interviews and metacognition test questions; (5) The results obtained were collected, and conclusions were drawn. In this study, the test of the validity of the findings used time triangulation, namely the technique of checking the validity of the data seen from different times.

\section{FINDINGS AND DISCUSSION}

This study uses a logical thinking ability test to determine the subject. The logical thinking ability test results on 36 students ( 32 female students and four male students) showed three students with logical thinking abilities in the abstract operation stage, 17 students with transitional stage logical thinking skills, and 16 students with concrete logical thinking skills.

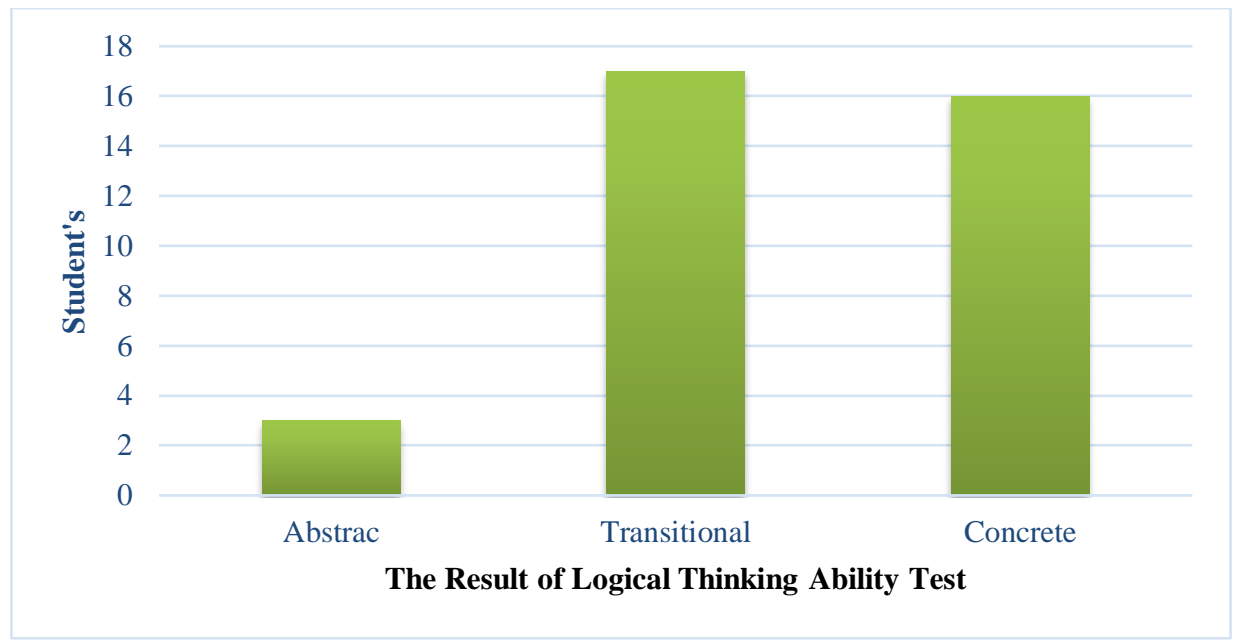

Figure 1. Student's Logical Thinking Ability Test Result

Based on the data analysis results, the researcher determined and selected three students of the same sex and different logical thinking skills who could think logically in the abstract, transitional, and concrete operational stages. Detailed data from the test results on research subjects can be seen in Table 1.

Table 1. Classification of Logical Thinking Ability Test Result

\begin{tabular}{ccccc}
\hline No. & Subject & Sex & Skor & Logical Thinking Ability \\
\hline 1 & CYC & Female & 9 & Abstract \\
\hline 2 & DWP & Female & 5 & Transitional \\
\hline 3 & EK & Female & 3 & Concrete \\
\hline
\end{tabular}

The subject with initial CYC got a nine score that means she had an abstract logical thinking ability. The subject with initial DWP got a score of five that means she had transitional logical thinking ability. The subject with initial EK got a score of three, which means she concreted in logical thinking ability. In the discussion, another term is used, namely CYC as subject 1, DWP is called subject 2, and EK is called subject 3 .

\section{The Research Result Based on Subject 1}

The metacognition test was given to subject one while being interviewed. The subject can solve the problem well, explain information related to the problem, and evaluate the activities carried out. 
1) Planning Stage

At this stage, the subject identifies the problem by reading the problem. As shown in the following interview transcript, the subject sees a known relationship and is asked by restating information and initial clues to the problem.

Interviewer : From what you read, what do you get? you try to tell

Subject $1 \quad$ : So in question number 1, given the information ee, for taxi passengers the cost to open the door is 12,00o, for the vehicle cost per kilometer is 6,ooo, so every 1 kilometer is to open the door and there is a price per kilometer, like that.

Other than that subject chooses the material of arithmetic sequences and series in solving the problem. Besides that, the subject can mention the elements needed in carrying out the work using arithmetic sequence and series material such as terms and differences. The subject said there was a different first term and the terms being asked. The subject calculates the time needed to solve the problem is 3-4 minutes. In ensuring conformity of the information with the problem, the subject restates the complete problem with what was asked, as shown in the following interview script.

Interviewer : What material can you help solve this problem?

Subject $1 \quad$ : Arithmetic and geometric line matter

Interviewer : Is the material that helps you correct? how do you know

Subject $1 \quad$ : Yes, because he knows there is a first-term and also different tribes in question.

Interviewer : Approximately how much time will you need to solve this problem?

Subject $1 \quad:$ 3-4 minutes

2) Monitoring Stage

The subject writes what is known, asks, and writes the formula used to solve the problem. The subject sees essential things that the subject records in known things. The subject stops the calculation when it is sufficient. Decide what steps to take next, whether changes need to occur or move to other instructions, as shown in the following interview transcript.

Interviewer : What steps did you take to solve this problem?

Subject $1 \quad$ : Read the questions first, then enter the information you know, write down what was asked, then enter the formula for the things that were asked

Interviewer : Is this the step that you took is complete?

Subject 1 : Yes, it's finished

\section{3) Evaluation Stage}

The subject re-checks each step that has gone well by correctly entering the number into the known formula. Subjects answered the same thing when asked whether the job was correct or not. The subject did not double-check whether other special considerations were needed in solving the problem because the subject only believed in one way to solve the problem, namely using the arithmetic sequence and series formulas. The subject estimates other possible ways to solve these problems, namely the manual method. Still, the subject is more comfortable using the arithmetic sequence and series formulas. It feels the material is easy to understand and the most effective to use, as shown in the following interview script. 


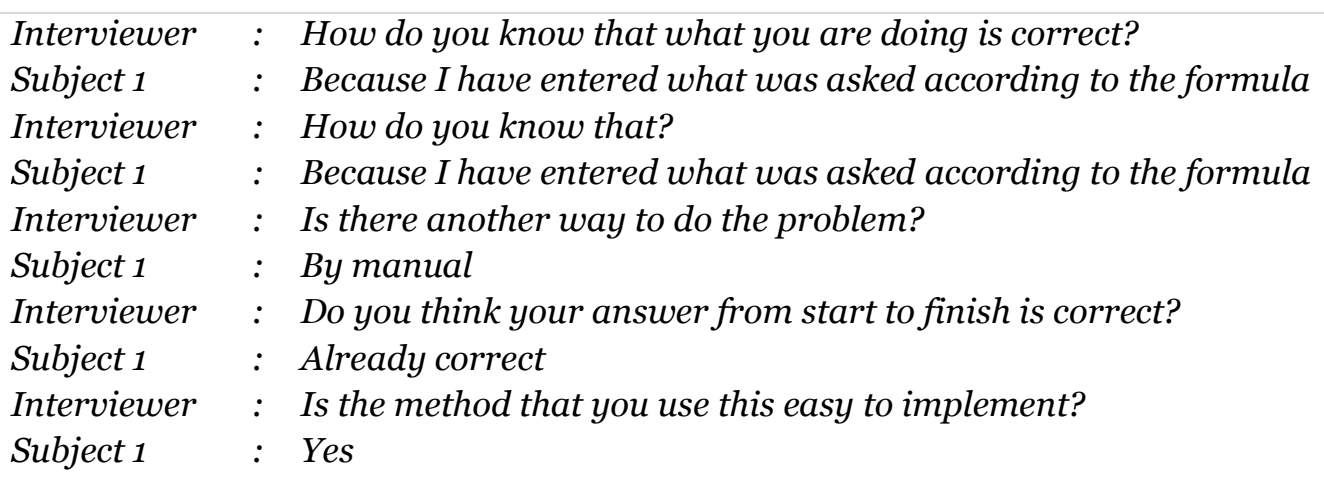

Besides, the subject's work results can be seen from the answers to the questions given. The subject works on these questions in detailed and ordered steps as in the following figure.

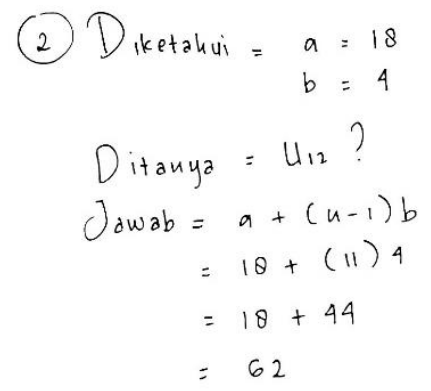

Figure 2. Subject 1 Work Results in Item Number 2

\section{The Research Result Based on Subject 2}

Subject 2 was given a metacognition test while being interviewed. The subject can solve the problem, but subject two takes longer to solve the problem.

1) Planning Stage

The subject can retell the problem at hand. Subjects describe information and initial instructions related to problems with reading and understanding. The subject uses arithmetic material to arrange things that must be done. Knowledge of the material to be used determines the subject's ability to determine the solution to the problem at hand. The subject stated that the time needed to solve the problem was 5-15 minutes, depending on the problem's difficulty level. The subject ensures the conformity of information with the problem by reading and understanding the problem at hand, as shown in the following interview script.

$\begin{array}{ll}\text { Interviewer } & : \text { What information do you get after reading and understanding the question? } \\ \text { Subject } 2 & : \text { In the cinema, there are } 15 \text { seats in the front row and the back row there are } \\ \text { always three more seats from the front row, so here it explains that there are } & \\ & \begin{array}{l}15 \text { seats in the front row, and the number of seats in the row behind it is more } \\ \text { than the means that behind him } 15 \text { seats are always exceeded by three } \\ \text { means } 18 . \text { Then it is asked how many seats are in row } 12\end{array} \\ \text { Interviewer } & : \text { How do you know that? } \\ \text { Subject } 2 & : \text { Because I've read it } \\ \text { Interviewer } & : \text { What material can you help solve this problem? } \\ \text { Subject } 2 & : \text { Arithmetic } \\ \text { Interviewer } & : \text { Approximately how much time will you need to solve this problem? } \\ \text { Subject } 2 & : \text { 1O minutes }\end{array}$

2) Monitoring Stage

The subject calculates using a formula to solve the problem. Steps were taken by written subjects in working on the given worksheets. The subject analyzes important information to 
remember from the known things and their relationship to the material known to the subject. The subject is hesitant about the answer given but recalculates the answers previously written to make sure the steps taken are correct, as shown in the following interview script

The steps that are carried outgoing, good show how the subject works like the following figure.

$\begin{array}{lll}\text { Interviewer } & : \text { What steps did you take to solve this problem? } \\ \text { Subject } 2 & : \text { I will count it after this, } \\ \text { Interviewer } & : \text { Then what steps did you take? Or is it finished? } \\ \text { Subject } 2 & : \text { Already completed }\end{array}$

$$
\begin{aligned}
S_{n} & =\frac{n}{2} \cdot(2 a+(n-1) b) \\
& =\frac{10}{2}(15 \cdot 2+(10-1) b) \\
& =5(30+27) \\
& =5.57 \\
& =255
\end{aligned}
$$

\section{Figure 3. Subject 1 Work Results in Item Number 3}

3) Evaluation Stage

The subject re-checks every step that has gone well. What the subject does in checking is reexamining. The subject re-checks the answers given by counting. The subject estimates other ways to solve the problem. Still, the subject uses a way that is deemed manageable and effective by using arithmetic sequence and series material, as shown in the following interview script.

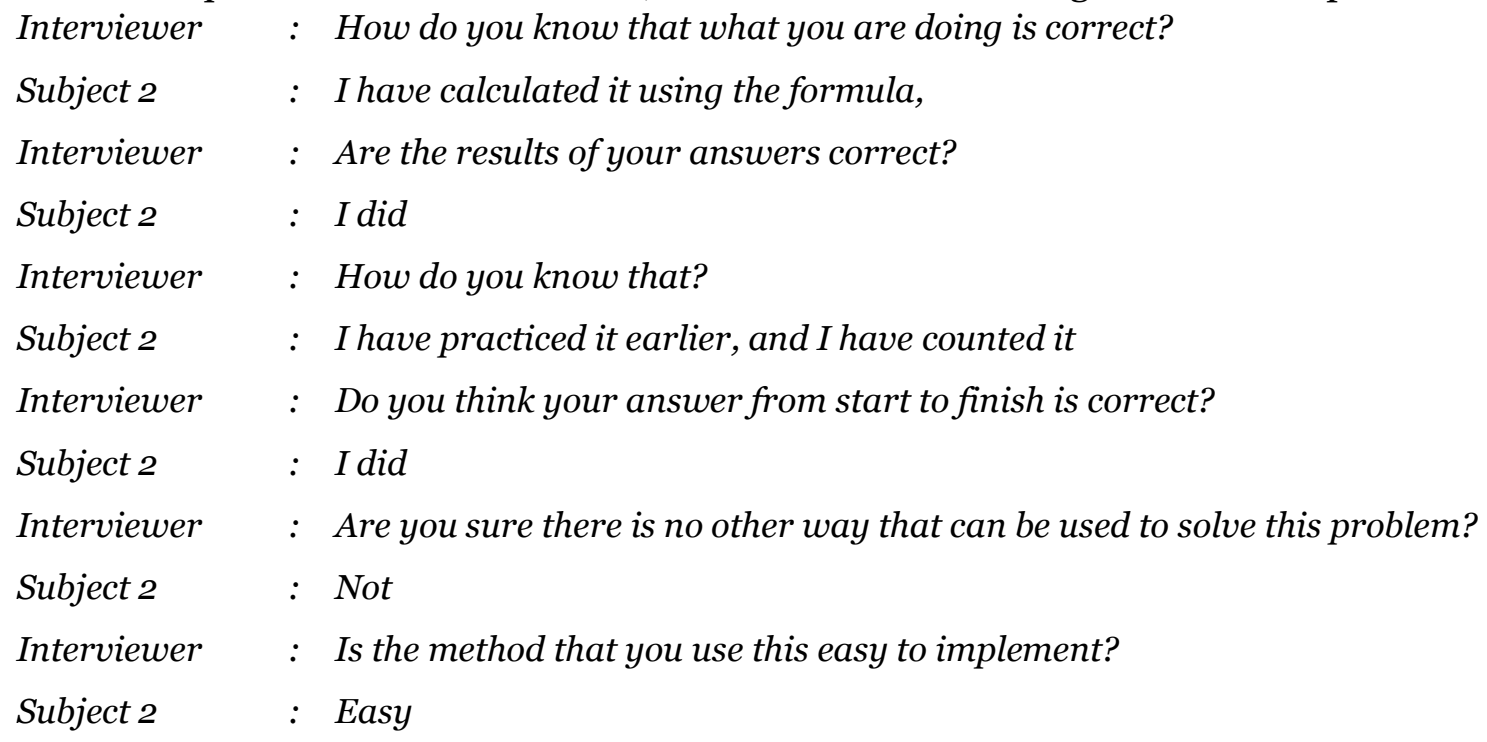

\section{The Research Result Based on Subject 3}

Subject 3 was given a metacognition ability test while being interviewed. The subject has not been able to solve the problem in detail and well. The subject does not evaluate the work already done.

1) Planning Stage

The subject of determining initial information and initial instructions relating to the problem is reading. The subject cannot describe what information is contained in the problem and what information is asked of the problem. The subject said that the material that can be used is an 
arithmetic sequence and series material. The subject concluded this by looking back at the problem. The subject estimated the time needed to solve one problem to be 15 minutes. The subject has not been able to ensure the suitability of the information with the problem. The subject needs the suitability of information to estimate what steps can be taken to solve the problem. Besides being appropriate, the subject's information is also indistinguishable, as shown in the following interview script.

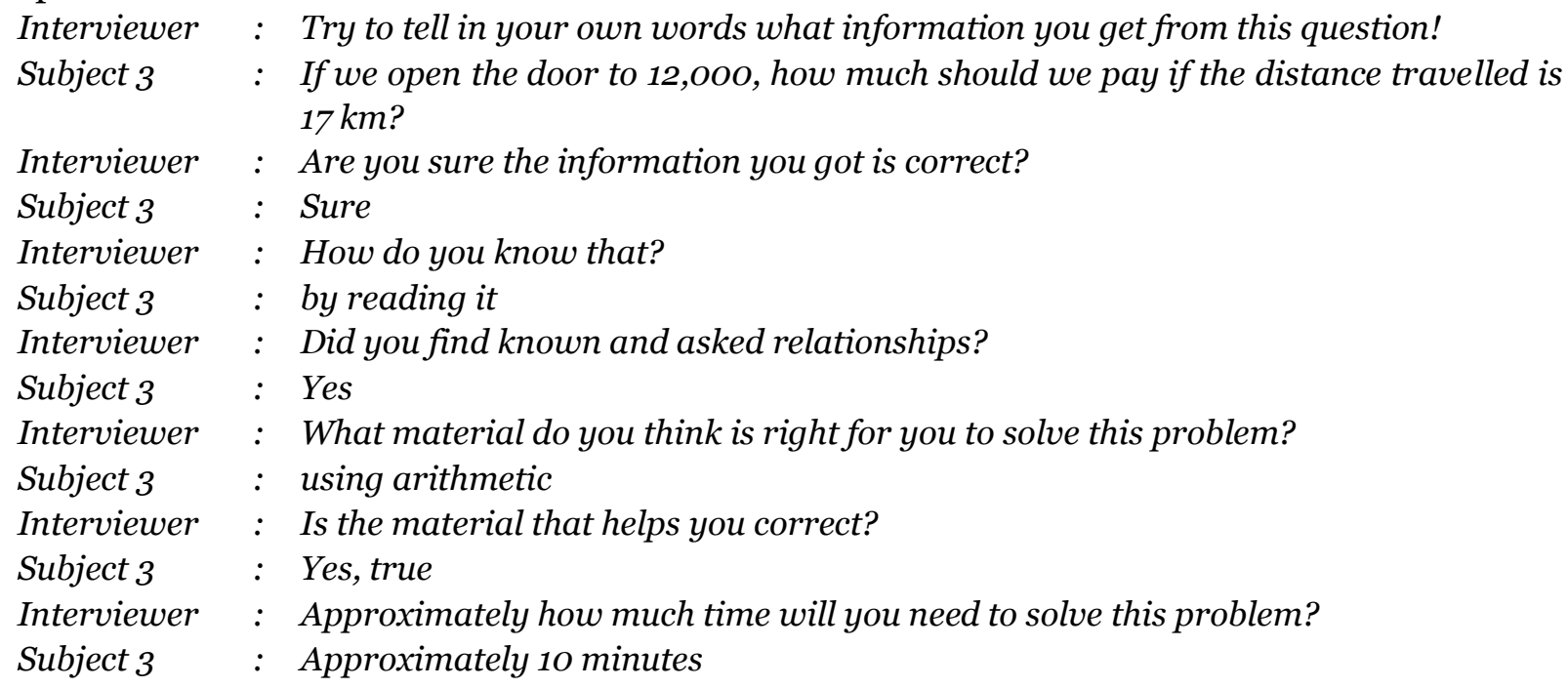

\section{2) Monitoring Stage}

The subject identifies the steps to solve the problem by calculating. The subject ends the steps taken when the work is done deemed complete. The subject does not check vital information to remember while working. The subject did not write down in detail the steps taken to solve the problem. In doing so, the subject only writes down the answers that the subject considers correct.

$\begin{array}{ll}\text { Interviewer } & : \text { Have you completed the steps taken? } \\ \text { Subject } 3 & : \text { I did } \\ \text { Interviewer } & : \text { Is there anything else you want to do? } \\ \text { Subject } 3 & : \text { They are already completed. } \\ \text { Interviewer } & : \text { How do you know that what you are doing is correct? } \\ \text { Subject } 3 & : \text { count, Insha Allah, it's true } \\ \text { Interviewer } & : \text { Does your job match what is known in the questions? } \\ \text { Subject } 3 & : \text { Yes, Insha Allah }\end{array}$

\section{3) Evaluation Stage}

The subject states that the answer given is correct by counting it. The subject does not re-check the work but is sure of the answers that have been written. The subject can estimate other possible ways that can be used to solve the problem, but this method takes longer. The subject identifies the method used in solving the problem most easily. The subject confirms that the method used in solving the problem is the most effective way.

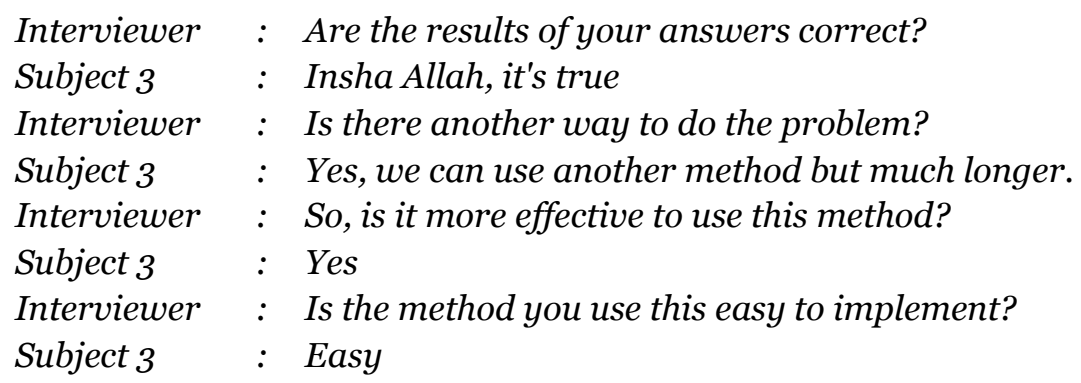


The results showed that formal operational subjects could correctly evaluate the results of their written work so that subjects in this category could answer all problem questions with the correct final result. All students who are research subjects in formal and transitional operations can identify examples of implementing strategies carried out for other similar problems. At the same time, concrete operational subjects have not been able to do so. This study results that children who enter formal operations can measure their abilities, knowledge, goals, and steps to achieve them. In other words, they can plan, make decisions and take strategies or alternative problem-solving. The metacognition process that must be carried out to have this ability starts by planning solutions, monitoring actions when making decisions, and taking strategies, then evaluating actions to assess actions and determine alternative solutions to problems.

Students with a cognitive development level everyday operations can learn abstraction, experience relationships more quickly and clearly, work based on their plans and initiatives. Students in this category can also be trained to self-diagnose and plan for improvement in their work. Students in this category are very likely to carry out the metacognition process well. Meanwhile, students' metacognition in solving math problems of upper-class students can evaluate all actions well to get good results (Novita et al., 2018; Nugrahaningsih, 2012). They are aware of the process and the results of their thinking in solving problems (Khairunnisa \& Setyaningsih, 2017; Nur Aini, 2017; Setyadi, 2018).

Students in the formal operational category can also consistently answer all problems with the correct final result. They can develop their metacognition process well so that they can successfully solve the given problem. These results are under several researchers' opinions (Hastuti et al., 2016; Panaoura \& Philippou, 2007; Wismath \& Orr, 2015), who suggest that his metacognitive activity influences a person's success in solving problems. Different results are shown by concrete operational subjects who have problems developing their metacognitive activities when solving problems. They have not measured their abilities well even though they understand and know the knowledge that must be possessed, the objectives, and the steps to be used when solving problems.

The metacognition profile of SMK students in solving problems in terms of students' logical thinking abilities, and it can be concluded that students in the concrete operational stage in completing the metacognition test went through all stages, namely the planning, monitoring and evaluation stage. The subject can describe the initial information at the planning stage, but it is not yet detailed and complete. The subject calculated the time needed to be 5-15 minutes. At the monitoring stage, the subject counts to determine which steps are going well. In the evaluation stage, the subject does not check again, and the subject only sees the method used is the easy way. For students, the transitional stage in completing the metacognition test goes through all stages, namely the planning, monitoring, and evaluation stages. At the planning stage, the subject can retell the problem in detail. The subject estimates the time needed to solve the problem is 5-15 minutes, depending on the question's difficulty level. At the monitoring stage, the subject calculates using a formula to solve the problem. The subject can determine the suitability of the information with the problem. The subject re-examines the work done; the subject sees the method used as easy and effective.

Moreover, students completing the metacognition test in the abstract operation stage went through all stages, namely the planning, monitoring, and evaluation stages. In the planning stage, the subject can retell in detail. The subject estimated the time needed to solve the problem to be 3-5 minutes. The subject's monitoring stage writes what is known, asked, and entered the formula to solve the problem. The subject can determine the suitability of the information with the problem. The subject re-examines the work done; the subject sees the method used easily and effectively.

\section{CONCLUSION}

The subject of the abstract operation stage fulfilled the metacognition stage by re-describing the problem given, knowing the relationship between what was known and what was asked, working 
on the problem by writing down what was known and asked and entering it into the formula, and also checking again by entering the number that was asked-known to be a known formula. Transition stage subjects fulfill the metacognition stage by describing initial information and instructions, performing problem-solving steps, and counting to check completed work. The subject of concrete operations fulfills the metacognition stage by stating information and instructions that are non-specific and detailed. The subject has not been able to state the proper steps to ensure the information's conformity with the problem, and the subject sees what is done by calculating.

Further researchers can follow up these results to examine the relationship between cognitive development at various levels of education with students' metacognition abilities. The metacognition ability of concrete operational students at the primary and junior high school levels may differ from the concrete operational students' metacognition abilities at the high school level. Besides, further researchers can also develop research on the correlation between students' cognitive development level with mathematical problem-solving abilities.

\section{REFERENCES}

Akben, N. (2020). Effects of the Problem-Posing Approach on Students' Problem Solving Skills and Metacognitive Awareness in Science Education. Research in Science Education. https://doi.org/10.1007/s11165-018-9726-7

Balcomb, F. K., \& Gerken, L. A. (2008). Three-year-old children can access their own memory to guide responses on a visual matching task. Developmental Science. https://doi.org/10.1111/j.1467-7687.2008.00725.x

Bitner, B. L. (1991). Formal operational reasoning modes: Predictors of critical thinking abilities and grades assigned by teachers in science and mathematics for students in grades nine through twelve. Journal of Research in Science Teaching. https://doi.org/10.1002/tea.3660280307

Bunce, D. M., \& Hutchinson, K. D. (1993). The use of the GALT (Group Assessment of Logical Thinking) as a predictor of academic success in college chemistry. Journal of Chemical Education, 70 (3), 183. https://doi.org/10.1021/edo70p183

Fadiana, M., Amin, S. M., Lukito, A., Wardhono, A., \& Aishah, S. (2019). Assessment of seventh grade students' capacity of logical thinking. Jurnal Pendidikan IPA Indonesia, 8(1), 75-80. https://doi.org/10.15294/jpii.voio.11644

Fisher, J., \& Wood, E. (2012). Changing educational practice in the early years through practitionerled action research: An Adult-Child Interaction Project. International Journal of Early Years Education. https://doi.org/10.1080/o9669760.2012.715400

Hassan, N. M., \& Rahman, S. (2017). Problem solving skills, metacognitive awareness, and mathematics achievement: A mediation model. New Educational Review. https://doi.org/10.15804/tner.2017.49.3.16

Hastuti, I. D., Nusantara, T., \& Susanto, H. (2016). Constructive Metacognitive Activity Shift in Mathematical Problem Solving. Educational Research and Reviews. https://doi.org/10.5897/ERR2016.2731

Khairunnisa, R., \& Setyaningsih, N. (2017). Analisis Metakognisi Siswa Dalam Pemecahan Masalah Aritmatika Sosial Ditinjau Dari Perbedaan Gender. Konferensi Nasional Penelitian Matematika Dan Pembelajarannya II.

Kincal, R. Y., \& Yazgan, A. D. (2010). Investigating the Formal Operational Thinking Skills of 7th and 8th Grade Primary School Students According to Some Variables. Ilkogretim Online.

Larkin, S. (2006). Collaborative group work and individual development of metacognition in the early years. Research in Science Education. https://doi.org/10.1007/s11165-006-8147-1

Moore, J. C. (2012). Transitional to Formal Operational: Using Authentic Research Experiences to Get Non-Science Students to Think More Like Scientists. European J Of Physics Education.

Novita, T., Widada, W., \& Haji, S. (2018). Metakognisi Siswa dalam Pemecahan Masalah Matematika 
Siswa SMA dalam Pembelajaran Matematika Berorientasi Etnomatematika Rejang Lebong. Jurnal Pendidikan Matematika Raflesia.

Nugrahaningsih, T. K. (2012). Metakognisi Siswa Sma Kelas Akselerasi Dalam Menyelesaikan Masalah Matematika. Magistra.

Nur Aini, A. (2017). Profil Metakognisi Siswa Dalam Memecahkan Masalah Matematika Ditinjau Dari Kemampuan Matematika. MATHEdunesa.

Ojose, B. (2015). Applying Piaget's Theory of Cognitive Development to Mathematics Instruction. The Mathematics Educator.

Panaoura, A., \& Philippou, G. (2007). The developmental change of young pupils' metacognitive ability in mathematics in relation to their cognitive abilities. Cognitive Development. https://doi.org/10.1016/j.cogdev.2006.08.004

Sandi-Urena, S., Cooper, M. M., \& Stevens, R. H. (2011). Enhancement of metacognition use and awareness by means of a collaborative intervention. International Journal of Science Education. https://doi.org/10.1080/09500690903452922

Sart, G. (2014). The Effects of the Development of Metacognition on Project-based Learning. Procedia - Social and Behavioral Sciences. https://doi.org/10.1016/j.sbspro.2014.09.169

Setyadi, D. (2018). Proses Metakognisi Mahasiswa dalam Memecahkan Masalah Matematika (Studi Kasus Pada Mahasiswa Pendidikan Matematika UKSW). Kreano, Jurnal Matematika KreatifInovatif.

Syahbana, A. (2012). Peningkatan Kemampuan Berpikir Kritismatematis Siswa Smpmelalui Pendekatan Contextual Teaching And Learning Ali. Edumatica.

Wismath, S. L., \& Orr, D. (2015). Collaborative Learning in Problem Solving: A Case Study in Metacognitive Learning. The Canadian Journal for the Scholarship of Teaching and Learning . https://doi.org/10.5206/cjsotl-rcacea.2015·3.10 